\title{
ULTRA-LOW CONCENTRATIONS OF BENZIMIDAZOLE DERIVATIVES CAN INCREASE BULL AND HORSE SEMEN RESISTANCE AT CRYOPRESERVATION AND UNDER THE INFLUENCE OF DAMAGING FACTORS
}

\section{E.V. NIKITKINA ${ }^{1}$, I.Sh. SHAPIEV ${ }^{1}$, K.V. PLEMYASHOV ${ }^{1}$, S.A. KHARITONOV²}

\author{
${ }^{1}$ All-Russian Research Institute of Farm Animal Genetics and Breeding, Federal Agency of Scientific Organizations, \\ 55-a, Moskovskoe sh., pos. Tayrlevo, St. Petersburg, 196625 Russia, e-mail nikitkinae@mail.ru (corresponding \\ author), shapievism@bk.ru, kirill060674@mail.ru; \\ ${ }^{2}$ St. Petersburg Agrarian University, 2, Peterburgskoe sh., St. Petersburg, 196601 Russia, e-mail seshar@gmail.com \\ (corresponding author) \\ ORCID: Nikitkina E.V. orcid.org/0000-0002-8496-5277 \\ The authors declare no conflict of interests
}

Received December 30, 2016

\section{Abstract}

One of the possible ways to improve sperm cryopreservation is to find how to increase the resistance to damaging effects of low temperatures. Here we summarize our findings on the bull and stallion semen cryoresistance as influenced by ultra-low concentrations of biologically active substances, the ethyl-1-benzimidazol-2-yl-sulfanyl, 2-ethylsulfanyl-benzimidazol-1-yl and 2-benzimidazol-1-yl-acetic acid. It was found that these substances increased survivability of bull semen during storage in lactose-citrate semen extender. The best motility and vitality of sperm after freezing and thawing was observed when sperm was diluted by extender with added 2benzimidazol-1-yl-acetic acid in the ultra-low concentrations of $10^{-13}$ to $10^{-15} \mathrm{M}$. The viability of sperm to $10 \%$ motility was $73 \%$ higher as compared to control. Similarly, freezing equine sperm in extender supplemented with 2-benzoimidazol-1-yl-acetic acid at $10^{-13} \mathrm{M}$ was more effective: the semen survival after freezing and thawing was $8.1 \%(\mathrm{P}<0.01)$ higher than that in the control, and the intactness of acrosome was $1.9 \pm 0.63 \%$ higher $(\mathrm{P}<0.05)$. 2-Benzimidazol-1-ylacetic acids also improved semen vitality at $40{ }^{\circ} \mathrm{C}$ when different osmolarity and after cold shock. It can be assumed that the observed phenomenon is likely due to the protective effect of 2benzimidazole-1-yl-1-acetic acid to plasma membrane and the mitochondria membrane structure of spermatozoa. Study of respiration in bovine sperm after freezing and thawing confirmed this assumption. Indeed, dinitrophenol almost equally increased cell respiration despite the presence or absence of 2-benzimidazole-1-yl-1-acetic acid in the semen extender while succinate, which penetrates through the damaged membranes, had less stimulating effect when 2-benzimidazole-1-yl-1acetic acid added. The studies suggested the hypothesis that benzimidazole, a biologically active substance, at ultra-low concentrations can bind to a receptor on the sperm outer membrane resulting in the cell membrane restructuring. At the same time, the changes in viscosity of water associated with the membrane proteins may occur due to hydrogen bonds between water molecules and acid residues of benzimidazole molecules. As a result stability of the membrane structures to damaging effect of varying osmotic pressure increases. Possibly crystal formation of water associated with the cell membranes is decreasing during freezing that also reduces the damaging effect.

Keywords: sperm, freezing, benzimidazole, ultralow concentrations, cell membrane, mitochondria, bulls, stallions

Despite widespread use of cryopreserved sperm in breeding various types of farm animals, the death of up to 40-50\% of germ cells after freezing remains a problem for the practice of artificial insemination, so the search for ways to make spermatozoa resistant to the damaging effect of low temperatures is still relevant [1-5].

Nonspecific increase in cell resistance under the influence of chemicals of different nature in subthreshold doses and concentrations, several orders of magnitude lower than the sub-toxic, has been described for a long time. In the 
domestic literature, early publications on this topic include studies that confirmed an increase in the time of spermatozoa survivability under the influence of subthreshold doses of a number of agentsю e.g. drugs, urea, inhibitors of metabolism, etc. [6-11]. Later, substances with the ability to cause an increase in cell resistance at concentrations several orders of magnitude lower than the subtoxic levels were found. Thus, it has been shown that benzimidazole and its derivative dibasol in concentrations of $10^{-3}-10^{-11} \mathrm{M}$ promotes resistance of cells and tissues to the damaging effects of low and high temperatures [12-14].

In the last 20 years the attention of researchers has been attracted by the phenomenon of the effectiveness of ultra-low doses (ULD, $10^{-12}-10^{-15} \mathrm{M}$ ) substances with respect to biological objects. First of all, the reason is that many compounds in ULD can cause response reactions that are comparable and even more significant than at substantially higher concentrations [15, 16]. Attempts to explain the mechanism of the biological effect of physical and chemical factors in the ULD [17-21] have not led to a single opinion to date. Nevertheless, ULD in a number of cases found a successful application in medicine [22-24] and veterinary medicine $[25,26]$.

We first studied the effect of benzimidazole derivatives on the resistance of bull and stallion spermatozoa to the damaging effect of low and ultra-low temperatures during cryopreservation, and it was shown that the greatest activity and safety were noted when 2-benzimidazole-1-yl-1-acetic acid of at an ultralow concentration of $10^{-12}-10^{-15} \mathrm{M}$ was introduced into the medium for semen freezing.

The aim of this work is to study the effect of low and ultra-low concentrations of benzimidazole derivatives on the survivability of spermatozoa during dilution, freezing and thawing, their resistance to cold shock in the media with different osmolarity.

Technoque. Benzimidazole derivatives were synthesized at the Department of Organic Chemistry of the St. Petersburg State Agricultural University. Used concentrations of the substances in the diluent were $10^{-3}, 10^{-5}, 10^{-11}$, $10^{-13}$, and $10^{-15} \mathrm{M}$.

The experiments used sperm of black-and-white bulls $(n=11)$ of Leningrad type (FGUP Nevskoe, Leningrad region) and Trakehner, Hanoverian, Arabian and Holstein stallions $(n=10)$ (OOO Cowboy, Malanichevs farm and private owners, Leningrad region). The bull sperm had an initial mobility of 5-6 points (because of this values the samples were not allowed to freeze for production purposes; when measuring respiration rate, samples with greater mobility were used), stallion sperm had 7-8 points. To compare the experiment options, each ejaculate was divided into equal parts.

When determining the resistance of bull spermatozoa to changes in osmotic pressure and cold shock, an aqueous lactose solution was a diluent. Control was a solution with an osmolarity of $336 \mathrm{mosm} / 1$, containing $11.5 \mathrm{~g}$ of lactose per $100 \mathrm{ml}$ of water; to increase or decrease osmolarity in the series 246, 276, 306, 336, and $366 \mathrm{mosm} / 1$, the amount of lactose was increased or decreased (by $1.02 \mathrm{~g}$ per $30 \mathrm{mosm} / \mathrm{l})$. The procedure for sample freezing corresponded to the interstate standard (GOST 26030-2015) [27]. Cold shock of bull spermatozoa was caused by a decrease in the temperature of diluted semen from 20 to $4^{\circ} \mathrm{C}$ for $2 \mathrm{~min}$.

The sperm of the stallions were diluted in Kenney medium (49 $\mathrm{g}$ of Dglucose, $24 \mathrm{~g}$ of dried milk, $40 \mathrm{mg}$ of gentamicin, 1 liter of distilled water) in a volume ratio of $1: 3$, then centrifuged for $8 \mathrm{~min}$ at $600 \mathrm{~g}$. The spermatozoa residue was suspended in Kenney medium and diluted 100 million cells/ml concentration, the semen was packed into $0.5 \mathrm{ml}$ straws, cooled at $4{ }^{\circ} \mathrm{C}$ for $90 \mathrm{~min}$ and 
frozen in liquid nitrogen vapor for $12 \mathrm{~min}$ at $110{ }^{\circ} \mathrm{C}$, then lowered in liquid nitrogen. The stallion sperm was thawed at $37{ }^{\circ} \mathrm{C}$ for $1-2 \mathrm{~min}$.

The volume, number and mobility of spermatozoa (complete absence as 0 points, $100 \%$ as 10 points) were assessed by conventional methods. Morphology and condition of the acrosome cap were studied with phase-contrast light microscopy. The time of the survivability of the bull sperm was expressed in hours to the preservation of $10 \%$ of mobile cells and to the complete loss of mobility.

The respiratory activity of the cells was determined according to the description [28] on a polarograph LP 7 (Czech Republic) with a Clark platinum electrode. The incubation medium was $6 \%$ glucose, in which sperm (50100 million spermatozoids per $\mathrm{ml}$ ) was successively added to final concentration, potassium succinate was a substrate $\left(1.0 \times 10^{-3}-2.5 \times 10^{-3} \mathrm{M}\right)$, and proton ionophore 2.4-dinitrophenol (DNP, $2.5 \times 10^{-5} \mathrm{M}$ ) served as classical uncoupler of cellular respiration and phosphorylation.

Damage to the plasma membranes of stallion spermatozoa was assessed using Sperm VitalStain dye (Nidacon International AB, Sweden). Staining was performed in Eppendorf tubes (50 $\mu$ l of sperm were mixed with $50 \mu$ l of dye) and smears were made on slide glasses. The preparations were examined with $\times 100$ magnification (lens) and oil immersion, counting at least 200 cells in each sample (white cells mean no damage, red or pink were spermatozoa with damaged membranes).

The Axio Imager visualization system (Carl Zeiss Microscopy $\mathrm{GmbH}$, Germany) was used for microscopy.

Data was processed in SigmaPlot 12.5 (Systat Software Inc., USA) and Micrisoft Excel programs. We performed a general statistical analysis and an estimation of the average difference between samples with pairwise coupled variants. The differences were considered statistically significant at $\mathrm{P}<0.05$. The tables show the mean $(X)$ and standard error of the mean $(\bar{x})$.

Results. One of the possible approaches to the practical solution of the preservation problem of cryopreserved spermatozoa is to find ways to increase their resistance to the damaging effect of low temperatures. To date, enough data have been accumulated on the effect of cooling on cells [29, 30], which allow us to draw definite conclusions about the mechanisms of damage and approaches to preventing these damages. It is possible to distinguish two types of damage to cellular structures that occur during the action of cold, i.e. associated with cooling prior to freezing and resulting from crystal formation during freezing. Among the factors influencing the survival of cells and tissues during cryopreservation, the cold shock [31] and fluctuations in osmotic pressure during dilution, freezing and thawing of sperm are distinquished.

When comparing the time of survivability of bull spermatozoa at $20{ }^{\circ} \mathrm{C}$ in the presence in the diluent medium of three benzimidazole derivatives in concentrations of $10^{-3}-10^{-15} \mathrm{M}$, it was found that the survival of bull spermatozoa during storage in the lactose-citrate medium was increased. The greatest positive effect was given by ethyl-1-benzimidazole-2-yl-sulfanyl at a concentration of $10^{-5} \mathrm{M}$ (46\% excess), 2-ethyl-sulfanyl-benzimidazole-1-yl at a concentration of $10^{-11} \mathrm{M}(59 \%)$ and 2-benz-imidazol-1-yl-1-acetic acid in concentrations of $10^{-11} \mathrm{M}, 10^{-13} \mathrm{M}$ and $10^{-15} \mathrm{M}$ (by $88-90 \%$ ).

Comparison of the effect of the most effective concentrations of the studied derivatives at an elevated plus temperature $\left(40^{\circ} \mathrm{C}\right)$ (Table 1$)$ showed that the greatest activity and survivability of bull spermatozoa after freezing-thawing was due to the presence in the medium for the semen dilution of 2benzimidazol-1-yl-1-acetic acid in ultra-low concentrations of $10^{-13}-10^{-15} \mathrm{M}$, or 
only 4-6 molecules of the test substance per spermatozoon. In this variant, the percentage of surviving spermatozoa (activity) was significantly higher (by 8$13 \%, \mathrm{P}<0.01)$ than in the control. The time of survivability until the mobility of $10 \%$ of the spermatozoa increased by $73 \%$, and the time until the mobility ceased completely exceeded the control by $85-90 \%$.

1. Survivability of bovine spermatozoa at $40{ }^{\circ} \mathrm{C}$ after freezing and thawing in a medium with ultra-low concentrations of benzimidazole derivatives $(n=7, X \pm \bar{x})$

\begin{tabular}{|c|c|c|c|}
\hline \multirow{2}{*}{ Option } & \multirow{2}{*}{$\begin{array}{l}\text { Activity after } \\
\text { thawing, point }\end{array}$} & \multicolumn{2}{|c|}{ Survivability time, hour } \\
\hline & & up to 1 point $(10 \%)$ & up to 0 point \\
\hline Control & $2,6 \pm 0,28$ & $1,5 \pm 0,18$ & $2,0 \pm 0,19$ \\
\hline \multicolumn{4}{|l|}{ Benzimidazole derivative, $\mathrm{M}$ : } \\
\hline ethyl-1-benzimidazol-2-yl-sulfanyl, $10^{-5}$ & $3,2 \pm 0,01$ & $2,3 \pm 0,22 *$ & $2,9 \pm 0,21 * *$ \\
\hline 2-ethylsulfanyl-benzimidazol-1-yl, $10^{-11}$ & $3,0 \pm 0,23$ & $2,0 \pm 0,23$ & $3,2 \pm 0,18^{* *}$ \\
\hline 2-benzimidazol-1-yl-1-acetic acid, $10^{-11}$ & $3,2 \pm 0,38^{* *}$ & $2,0 \pm 0,21$ & $2,9 \pm 0,24 * *$ \\
\hline 2-benzimidazol-1-yl-1-acetic acid, $10^{-13}$ & $3,9 \pm 0,26 * * *$ & $2,6 \pm 0,21^{* * *}$ & $3,7 \pm 0,21^{* * *}$ \\
\hline 2-benzimidazol-1-yl-1-acetic acid, $10^{-15}$ & $3,4 \pm 0,07^{* * *}$ & $2,6 \pm 0,09 * * *$ & $3,8 \pm 0,15^{* * *}$ \\
\hline
\end{tabular}

Similar results were obtained by freezing and thawing of stallion sperm in a medium with $10^{-13} \mathrm{M}$ 2-benzimidazol-1-yl-1-acetic acid. The number of mobile intact cells was $15.2 \pm 3.49$ million $/ \mathrm{ml}$ greater $(\mathrm{P}<0.01)$ than without supplement, the survivability of spermatozoa after freezing-thawing increased by $8.1 \%(\mathrm{P}<0.01)$, the preservation of the acrosome was $1.9 \pm 0.63 \%$ higher $(\mathrm{P}<0.05)$.

2. Survivability of bovine spermatozoa at $40{ }^{\circ} \mathrm{C}$ and different osmolarity under the influence of 2-benzimidazole-1-yl-1-acetic acid $\left(10^{-13} \mathrm{M}\right)(n=11, X \pm \bar{x})$

\begin{tabular}{|c|c|c|c|c|c|c|}
\hline \multirow{3}{*}{$\begin{array}{l}\text { Osmolarity, } \\
\text { mosm/1 }\end{array}$} & \multicolumn{6}{|c|}{ Mobile cells, $\%$} \\
\hline & \multicolumn{2}{|c|}{ after dilution } & \multicolumn{2}{|c|}{ after an hour at $40^{\circ} \mathrm{C}$} & \multicolumn{2}{|c|}{ after two hours at $40^{\circ} \mathrm{C}$} \\
\hline & control & experiment & control & experiment & control & experiment \\
\hline 366 & $28 \pm 4,8^{\mathrm{a}}$ & $42 \pm 5,8^{\mathrm{a}}$ & $10 \pm 0,9 \mathrm{~g}$ & $14 \pm 1,6^{\mathrm{g}}$ & 0 & 0 \\
\hline 336 & $60 \pm 3,2^{\mathrm{A}}$ & $60 \pm 3,2^{B}$ & $29 \pm 3,7 \mathrm{~d}$ & $41 \pm 3,3^{d}$ & $11^{\mathrm{i} \pm 2,4}$ & $26^{i} \pm 3,0$ \\
\hline 306 & $24 \pm 2,4^{b}$ & $40 \pm 4,4^{b}$ & $11 \pm 1,6^{\mathrm{e}}$ & $19 \pm 2,7 \mathrm{e}$ & 0 & $6 \pm 1,6$ \\
\hline 276 & $15 \pm 2,2^{c}$ & $31 \pm 4,0^{\mathrm{c}}$ & 0 & $12 \pm 1,5$ & 0 & 0 \\
\hline 246 & $4 \pm 2,4^{*}$ & $20 \pm 3,2^{*}$ & 0 & $6 \pm 1,8$ & 0 & 0 \\
\hline
\end{tabular}

N o t e. Bull sperm with initial activity of 5-6 points were used.

* Differences in variants aa, bb, cc, dd, ee, ii, Aa, Ab, Bb and Ba are statistically significant at $\mathrm{P}<0.01$, in gg - at $\mathrm{P}<0.05$.

2-Benzimidazole-1-yl-1-acetic acid at the same concentration of $10^{-13} \mathrm{M}$ positively influenced the stability of bovine spermatozoa as the osmolarity changed (Table 2). Immediately after dilution at room temperature $\left(20^{\circ} \mathrm{C}\right)$ in osmolarity isotonic for bovine sperm (336 mosm/1), 2-benzimidazole-1-yl-1acetic acid did not affect the cell activity compared to the control. However, after 1 and 2 hours after storage (at $40{ }^{\circ} \mathrm{C}$ ) in the presence of an additive, the motility of the spermatozoa in the isotonic medium turned out to be $12 \%$ and $15 \%$ higher, respectively $(\mathrm{P}<0.01)$, than in the control. With a decrease or increase in the osmolarity by $30 \mathrm{mosm} / 1$ to the isotonic level, the proportion of mobile cells in the sperm decreased immediately upon dilution (see Table 2), but in a medium with 2-benzimidazol-1-yl-1-acetic acid $\left(10^{-13} \mathrm{M}\right)$ only by 18 $20 \%$ compared to $32-36 \%$ in the control. In hypoosmotic conditions, a complete sperm death was observed after $1 \mathrm{~h}$ in the control, while in the experiment $6-12 \%$ of the cells retained motility. After $1 \mathrm{~h}$ in hyperosmotic conditions $(366$ mosm/l), the percentage of mobile spermatozoa in the experiment was significantly higher (by $14 \%, \mathrm{P}<0.05$ ) compared to the control.

Phase-contrast microscopy revealed no morphological differences in the acrosome and sperm flagellum between the experimental and control variants 
immediately after dilution, whereas different osmolarity of the medium led to a change in the safety and viability of the spermatozoa (see Table 2). After a cold shock in the control, $40 \%$ of the spermatozoa lost their mobility, while in $10^{-13}$ M 2-benzimidazole-1-yl-1-acetic acid, the motility of spermatozoa decreased by $26 \%$. It can be assumed that the observed increase in cell resistance to osmotic influence and cold shock is associated with the protective effect that the benzimidazole derivatives have on the membrane structures of spermatozoa.

As is known, the mobility and time of sperm survivability depend on energy supply, respiration and phosphorylation, and are directly related to the functional state of the mitochondria. The mitochondrial membranes are most sensitive to damaging factors [28]. Succinate enhances cellular respiration, penetrating only through the damaged plasma membrane, and DNP serves as an uncoupler of tissue respiration and oxidative phosphorylation [28]. In our experiments (Table 3), the stimulation of the respiration of bovine spermatozoa by succinate after freezing and thawing in the presence of 2-benzimidazole-1-yl-1acetic acid $\left(10^{-13} \mathrm{M}\right)$ was lower, and with DNP was higher than in control, that indicates a better energy supply when using an additive. This confirms the assumption that the ultra-low concentrations (doses) of the benzimidazole derivatives contribute to an increase in the stability of the spermatozoa membrane at an ultra-low temperature.

3. Change in respiratory rate in bovine spermatozoa under the influence of 2benzimidazole-1-yl-1-acetic acid $\left(10^{-13} \mathrm{M}\right)$ during freezing and thawing $(X \pm \bar{x})$

\begin{tabular}{|c|c|c|c|c|}
\hline \multirow{3}{*}{ Sperm } & \multirow{3}{*}{ Activity, point } & \multicolumn{3}{|c|}{ Respiration, $\mathrm{nmol} \mathrm{O}_{2 /} \min$} \\
\hline & & \multirow{2}{*}{ rate } & \multicolumn{2}{|c|}{ stimulation } \\
\hline & & & succinate $\mathrm{K}$ & DNP \\
\hline Freshly diluted & $7.0-8.0$ & $130.0 \pm 1.56$ & $1.06 \pm 0.012$ & $2.20 \pm 0.050$ \\
\hline \multicolumn{5}{|c|}{ After freezing and thawing: } \\
\hline control & $4.0-5.0$ & $77.0 \pm 3.82$ & $2.03 \pm 0.187$ & $1.57 \pm 0.029$ \\
\hline experiment & $4.5-6.0$ & $88.0 \pm 5.03$ & $1.47 \pm 0.730^{*}$ & $1.84 \pm 0.021^{*}$ \\
\hline
\end{tabular}

It is known that the cooling and freezing of spermatozoa results in the release of $\mathrm{K}^{+}$ions into the medium, which adversely affects cell vitality [31]. Benzimidazole derivatives serve as plasma membrane $\mathrm{H}^{+} / \mathrm{K}^{+}{ }_{-}$ATPhase inhibitors and prevent excess $\mathrm{K}^{+}$release. Apparently, interacting with the receptor on the outer cell membrane, benzimidazole derivatives cause a cascade rearrangement of the membrane structures. At the same time, the viscosity of water changes due to the occurrence of hydrogen bonds between molecules with the formation of clusters. As a result, the resistance of membrane to the damaging effect of osmotic pressure fluctuations occurring during freezing and thawing can increase. Besides, it is possible that when the water freezes, the character of crystal formation changes towards decreasing crystal size, which reduces their damaging effect. The absence of a pronounced effect of the substances at intermediate concentrations agrees with the classical theory of R.P. Stephenson [3234], according to which the maximum effect is achieved by binding the ligand to only a small part of the receptors.

So, when ultra-low concentrations $\left(10^{-13}-10^{-15} \mathrm{M}\right)$ of 2-benzimidazole-1yl-1-acetic acid was introduced into the medium used in freezing bull and stallion sperm, the spermatozoa were the most active and safe after freezing and thawing, cold shock, elevated temperature $\left(40^{\circ} \mathrm{C}\right)$ and when osmolarity changed (as it could be concluded from the time of survivability and the proportion of cells that remained mobile). Dinitrophenol almost equally strengthened cellular respiration in the experiment and in the control, while succinate, which penetrates through damaged membranes, had less stimulating effect in the presence of 2- 
benzimidazole-1-yl-1-acetic acid. The observed effect of 2-benzimidazole-1-yl-1acetic acid is presumably associated with its protective influence on the plasma membrane and the membrane structures of mitochondria in spermatozoa due to interaction with the receptor on the outer membrane, and, possibly, may be caused by the effect on the state of water molecules associated with membrane proteins.

\section{REFERENCES}

1. N a u me nk ova V.A., B rag in a E.E., Nikitk in a E.V. Resistance of stallion's sperm to freezing due to introduction of SKQ1 antioxidant to the medium. Agricultural Biology, 2012, 2: 64-68 (doi: 10.15389/agrobiology.2012.2.64eng) (in Engl.).

2. Dzhamaldinov A.Ch., Narizhny A.G., Kreindlina N.I., Kuripko A.N. Dostizheniya nauki i tekhniki APK, 2012, 8: 69-70 (in Russ.).

3. E $\mathrm{p}$ is h i n a T.M. Veterinarnaya patologiya, 2009, 2: 32-33 (in Russ.).

4. Chaveiro A., Liu J., Mullen S., Woelders H., Critser J.K. Determination of bull sperm membrane permeability to water and cryoprotectants using a concentration-dependent self-quenching fluorophore. Cryobiology, 2004, 48: 72-80.

5. Chaveiro A., Machado L., Frijters A., Engel B., Woelders H. Improvement of parameters of freezing medium and freezing protocol for bull sperm using two osmotic supports. Theriogenology, 2006, 65(9): 1875-1890 (doi: 10.1016/j.theriogenology.2005.10.017).

6. Al e k s a nd ro v V.Ya. Tsitologiya, 1965, 7(4): 10-15 (in Russ.).

7. Kurbatov A.D., Platov E.M., Korban N.V., Moroz L.G., Nauk V.A. Kriokonservatsiya spermy sel'skokhozyaistvennykh zhivotnykh [Farm animal semen cryoconcervation]. Leningrad, 1988 (in Russ.).

8. Amirat-Briand L., Bencharif D., Vera-Munoz O., Bel Hadj Ali H., Destrumelle S., Desherces S., Schmidt E., Anton M., Tainturier D. Effect of glutamine on post-thaw motility of bull spermatozoa after association with LDL (low density lipoproteins) extender: Preliminary results. Theriogenology, 2009, 71(8): 1209-1214 (doi: 10.1016/j.theriogenology.2008.10.002).

9. E1-Sheshtaw y R.I., E1-N at t a t W.S., S a b r a H.A. Effect of addition of catalase with or without L-tryptophan on cryopreservation of bull extended semen and conception rate. Global Veterinaria, 2013, 11(3): 280-284 (doi: 10.5829/idosi/gv.2013.11.3.7612).

10. Muino R., Pena A.I., Rodriguez A., Tamargo C., Hidalgo C.O. Effects of cryopreservation on the motile sperm subpopulations in semen from Asturiana de los Valles bulls. Theriogenology, 2009, 72(6): 860-868 (doi: 10.1016/j.theriogenology.2009.06.009).

11. Serhat Büyükleblebici, Pürhan Barbaros Tuncerb, Mustafa Numan Bucak, Ayse Ekend, Serpil Sarı̈̈zkan, Umut Tasdemir, Burcu Ün$1 \ddot{u}$ Endirlik. Cryopreservation of bull sperm: Effects of extender supplemented with different cryoprotectants and antioxidants on sperm motility, antioxidant capacity and fertility results. Anim. Reprod. Sci., 2014, 150(3-4): 77-83 (doi: 10.1016/j.anireprosci.2014.09.006).

12. S id o r o v O.A. Materialy nauchnogo soveshchaniya po voprosam farmakologicheskoi regulyatsii kletochnoi rezistentnosti [Proc. of Workshop on pharmacological regulation of cell resistance]. Leningrad, 1963: 18-20 (in Russ.).

13. Andre eva E.N. V sbornike: Sintez belka i rezistentnost' kletok [In: Protein synthesis and cell resistance]. Leningrad, 1971: 36-40 (in Russ.).

14. R u s i n V.Ya. Vliyanie dibazola na ustoichivost' kletok k povrezhdeniyu. V sb.: Sintez belka i rezistentnost' kletok [In: Protein synthesis and cell resistance]. Leningrad, 1971: 58-61 (in Russ.).

15. B u r l a k o va E.B. Vesti RAN, 1994, 64(5): 425 (in Russ.).

16. Cheretaev I.V., Korenyuk I.I., Gam ma T.V., K hus a inov D.R. Uchenye zapiski Tavricheskogo natsional'nogo universiteta im. V.I. Vernadskogo. Seriya Biologiya, khimiya, 2014, 27/66(4): 93-99 (in Russ.).

17. B u r l a k o v E.B. Rossiiskii khimicheskii zhurnal, 1999, 43(5): 3-11 (in Russ.).

18. Yamskova V.P., Krasnov M.S., Mal'tsev D.I., Kulikova O.G., Rybakova E.Yu., B ogdanov V.V., Y a mskov I.A. Materialy VI Mezhdunarodnogo kongressa «Slabye $i$ sverkhslabye polya $i$ izlucheniya $v$ biologii i meditsine» [Proc. VI International Congress «Low and superlow fields and radiations in biology and medicine»]. St. Petersburg, 2012: 98. Available http://www.biophys.ru/arch-ive/congress2012/proc-p98-d.pdf. No date (in Russ.).

19. B oldy reva L.B., B old y reva E.M. The model of superfluid physical vacuum as a basis for explanation of efficacy of highly diluted homeopathic remedies. Journal of Homeopathy \& Ayurvedic Medicine, 2012, 1(2): 2-6 (doi: 10.4172/2167-1206.1000109).

20. De nis ov Yu.D. To question on the proof parareceptor mechanism of action of ultra-low doses xenobiotics. EurAsian Journal of BioMedicine, 2011(4): 17-20.

21. Koreniuk I.I., Gamma T.V., Katiushyna O.V., Epishkin I.V., Khu - 
sainov D.R., Shylina V.V., Cheretaev I.V., Kolotilova O.I. Effect of concentration ultralow 1,5-benzodiazepinona-2 on the pain threshold in rats intoxicated with their organism cadmium chloride. European Journal of Natural History, 2013, 1: 16.

22. E z z H.A.A., E $1 \mathrm{k}$ a la R.S. Ultra-low-dose naloxone added to fentanyl and lidocaine for peribulbar anesthesia: A randomized controlled trial. Egyptian Journal of Anaesthesia, 2015, 3: $161-165$.

23. Yovel1 Y., Bar G., Mashiah M., Baruch Y., Briskman I., Asherov J., Lot a n A., Rigbi A., P a n k s p p J. Ultra-low dose buprenorphine as a time-limited treatment for severe suicidal ideation: a randomized controlled trial. The Am. J. Psychiat., 2016, 173(5): 491-498 (doi: 10.1176/appi.ajp.2015.15040535).

24. Doutremepuich S., Aguejouf O., Belon P. Effects of ultra-low-dose aspirin on embolization in a model of laser-induced thrombus formation. Semin. Thromb. Hemost., 1996, 22(S1): $67-70$.

25. Doutremepuich C., Aguejouf O., Desplat V., Eizayaga F.X. Paradoxical thrombotic effects of aspirin: experimental study on 1000 animals. Cardiovascular \& Hematological Disorders-Drug Targets, 2010, 10(2):103-110 (doi: 10.2174/187152910791292510).

26. S $\mathrm{l}$ a ve t s k a y a M.B., K a p a i N.A. Sverkhmalye dozy biologicheski aktivnykh veshchestv kak osnova lekarstvennykh preparatov [Ultra-low doses of bioactive substances as medicines]. Moscow, 2011 (in Russ.).

27. Sperma bykov zamorozhennaya. GOST 26030-2015 [Frozen semen of bull series. State Standard GOST 26030-2015]. Moscow, 2015 (in Russ.).

28. Moroz L.G., Shapiev I.Sh., Korban N.V. Sposob otsenki kachestva spermy sel'skokhozyaistvennykh zhivotnykh. A.S. 938990 (RF). Vserossiiskii NII genetiki i razvedeniya sel'skokhozyaistvennykh zhivotnykh (RF) № 293645. Zayavl. 09.06.1980 [Method to estimate farm animal semen quality. A.C. 938990 (RF). All-Russian Institute of Farm Animal Genetics and Breeding (RF) № 293645. Published June 30, 1982, Bul. № 24 (in Russ.).

29. B e lous A.M., Bondare nko V.A., Gulevski A.K. Kriobiologiya, 1987, 2: 3-10 (in Russ.).

30. Wolfw J., B ry a n t G. Cryobiology and anhydrobiology of cells. Sydney, 2004.

31. Ko no nov V.P., M a m b e tali e v M.S., T u rbi n V.F. Sel'skokhozyaistvennaya biologiya, 1993, 4: 47-52 (in Russ.).

32. S t e p h e n s o n R.P. A modification of receptor theory. Brit. J. Pharmacol., 1956, 11: 379-393.

33. Z a i t s e v S.V., E fa n o v A.M., S a z a n o v L.A. Rossiiskii khimicheskii zhurnal, 1999, 5(43): 28-33 (in Russ.).

34. Torchinski i A.A., Z he rnovkov V.E. Materialy I Ezhegodnoi molodezhnoi konferentsii IBKHF RAN «Biokhimicheskaya fizika» [Proc. I Annual Conf. of Young Scientists of IBCP RAS «Biochemical Physics»]. Moscow, 2001: 12-30 (in Russ.). 